\title{
DOES CONTEMPORARY COMPUTER-MEDIATED EPISTOLARY COMMUNICATION NEED PEDAGOGICAL INTERVENTIONS: THE CASE OF A STUDENT-TEACHER RELATIONSHIP
}

\begin{abstract}
The vast majority of messages we exchange on a daily basis is digital in its nature, and it could be said that computer-mediated communication has become common in all spheres of human endeavour. Despite the fact that CMC is an omnipresent phenomenon, it is usually the case that the choices regarding the language patterns to be used are made on our own; namely, it seems that there is no precise writing etiquette to be followed. This aim of this paper is to analyse the nature of computer-mediated communication performed in an academic environment. Using a language corpus composed of authentic email requests, sent by university students (Serbian native speakers) to a faculty staff member, in a time frame encompassing a few semesters, the language formulae used in email openings and closings and the orientation of the posed requestive head acts have been examined. The results of the analysis have shown that hearer orientation is dominantly employed in the requests and that the choices with regard to salutations and complimentary closings are rather inconsistent. Finally, the study answers questions regarding the appropriateness of such e-communication patterns; it also sheds some light on the role of educators and/or educational institutions in communication processes of this kind and their forms.
\end{abstract}

Keywords: computer-mediated communication, students, requests, power asymmetry, Serbian language.

\section{Introduction: Computer-Mediated Communication in an Academic Environment}

It is an inherent characteristic of humans to communicate - moreover, as Labov and Fanshel put it, "[o]ne of the most human things that human beings do is talk to one another" (Labov \& Fanshel, 1977: 1). When it comes to various forms of communicative processes, both written and spoken, there have always been certain conventions established for the purpose of better communication. Viewed through the prism of contemporary global society, it would seem that it has never been so easy and, at the same time, so difficult to communicate properly.

1 mprodanovic@singidunum.ac.rs 
Even though the first "reliable commercial computers" (Ceruzzi, 2003: 19) appeared during the late 1950s, it was roughly a decade later that people started using them for interpersonal communication (Hafner \& Lyon, 1996). Afterwards, in the early 1980s, the global network (the Internet) appeared, and it was during the following decade that it became available to a wide/-er audience (Messner \& Garrison, 2009). The network, which started spreading at an enormously rapid pace, numbered cca. 150 million users by the end of the $20^{\text {th }}$ century (Petrazzini \& Kibati, 1999), while recent estimatites have put the number of users at more than three billion (roughly 3.5 billion users, according to Internet Users in The World, 2016).

A vast number of the messages interchanged nowadays are in a form of language called Netspeak (Crystal, 2006). The language is not only used in electronic messages (aka emails), which represent contemporary epistolary forms, but is also a part of many other types of electronic communicative patterns which appear on the Internet. Even though the language used for the purpose of electronic communication often tends to map reallife communicative patterns, there are certain limitations which differentiate it, by and large, from face-to-face communication (Crystal, 2006).

First of all, with regard to emails, as a widespread method of computer-mediated communication, one cannot neglect many advantages - starting from the very fact one does not have to be online at the same time as the intended recipient, in order for the communication process to occur. Even though it is perceived as an asynchronous (Pritchard, 2007) form of communication, which involves a certain time gap in the process of message transmission, it is a fact that today, in the era of so-called smart phones and tablet devices, many people have their email accounts installed (and synchronised) on their smart gadgets, and they are thus often able to communicate as they go about their daily activities. This form is free from many socially-related prejudices; namely, social distance between the interlocutors, race and ethnicity, etc. are not relevant and transparent phenomena on the Internet, which enables communicators to compose their messages freely (Herring, 1996).

Apart from many advantages, computer-mediated communication also lacks some human-related rituals. One of the major issues is the fact that you cannot see your interlocutor's face, which makes you rather unsure about how he or she really feels. That is why people tend to use the so-called popular emoticons as a means of compensation in the processes of CMC (Crystal, 2006; Raymond, 1993). It is worth mentioning that the phenomenon of emoticons is even more frequent is text messages (aka SMS) than in emails (Frehner, 2008, according to: Dürscheid \& Frehner, 2013). The usage of this supporting means does not only represent communicators' facial expressions, but it also denotes closeness between the interlocutors.

Today, computer-mediated communication (Herring, 2003), performed in the form of emails, is a rather prominent form of communication in the academic environment. Students of the modern era - Millennials or Generation $Y$ (Howe \& Strauss, 2009) belong to the generations who have been raised with a strong support of the media, and, as a result, Generation $Y$ members actively exchange diverse types of electronic communicative forms. Hence, electronic messaging in academic communicative scenarios, the actors of which are students and their professors, has become a widely-employed communicative tool, and it is getting increasingly popular and common, especially in the implementation of the socalled just-in-time teaching, aka JiTT (Simkins \& Maier, 2010). 
Writing emails appears to belong to the scope of general knowledge in the era of modern communications, since an email has become as natural a communication channel as the telephone (Dürscheid \& Frehner, 2013). As a result, it is not always the case that educational institutions offer email templates that should be employed by their students (and/or their staff). Furthermore, it could be said that institutions rarely provide email etiquette guidelines as a part of their syllabi and curricula.

Being the most widely-used language ever (Crystal, 2003: 139; Modiano, 2009), English earned the status of a lingua franca language long ago. Anyhow, its influence is especially prominent in the mass media and the phenomenon of the Internet, areas in which English language patterns dominate (Durham, 2007). That is why it is not a rare occurrence that languages around the globe simply borrow and map expressions from English.

Despite the fact that English language influence is inevitable, due to its expansion and intense contacts with other languages (Filipović, 1996), the question arises regarding the potential need of world languages to establish their own patterns of computermediated communication. Namely, even though the patterns which usually represent socalled translational equivalents, i.e. calques (Bauer, 2004) in a target language (Filipović, 1986), have already become recognisable, it might be questionable whether and to what extent they are adequate for the nature of the language they are used in.

\section{Theoretical Implications}

\section{Pragmatic Insight into a Communicative Scenario}

While linguistic competence (Chomsky, 2006) denotes an individual's ability to use one language as a system and is referred to as "a knowledge of a language" (Chomsky, 2006: 27) itself, pragmatic competence represents the ability of an individual to use language appropriately in different social, cultural and situational contexts (Fraser, 2010; Grundy, 2008; Kecskes, 2014). Even though there is no prescribed way for using language material, we can undoubtedly differentiate between the language patterns we consider suitable for addressing, for example, our cousin and those used when addressing our employer.

The very moment we start uttering some verbal content, we do not only produce mere language material but also speech acts, which tend to emit a power similar to that of deeds (Austin, 1962; Searle, 1969). Then again, not each segment of the verbalised language material is of equal power and not each of them bears equal potential to endanger an autochthonous trait of individuality we all possess.

Among the uttered verbal acts which may have negative influence on the integrity of communicators, there is the act of requesting. In order for the speech act of requesting to occur, the situation of lacking/need on the part of the speaker is needed (Searle, 1969) and the processes of asking the hearer for the needed subject makes this process unpleasant, i.e. threatening for his face. Given these facts, if the aim of a communicative scenario, with the speech act of requesting, is not a disagreement between the communicators, special attention should be paid to the linguistic forms used. 


\section{Speech Act Orientation/Perspective}

There are many linguistic means that can soften the force of the words we utter. There is no doubt that the choice of the rather tentative modals could or would, as in the examples:

1) Would you mind sharing the information with me?

instead of:

2) Could you give me a hand with this difficult formula?

3) Give me the information!

4) Give me a hand!

would represent willingness on the part of the speaker to make his wording more acceptable for the hearer. Even the usage of negative constructions can positively influence the flow of communication. In the examples provided by Leech (Leech, 1983: 101):

5) I don't like Kenneth.

and

6) I dislike Kenneth.

the speaker's decision to mitigate the power of the words he utters by using a negative construction in the utterance which includes a positive verb to like (example 5), makes the used language material less threatening that the one with the verb to dislike (example 6).

Nonetheless, the moment we enter a communicative scenario, the linguistic choice that instantly becomes prominent is the one concerning the speech act perspective/orientation. Opting for the speaker-orientation of a speech act would denote that the speaker places the burden of the speech act before his face. So, if we compare the utterance (with the speech act of thanking), e.g.:

7) I would like to thank you for everything you have done for me so far. with the following one:

8) Thank you very much for everything!

we can conclude that the orientation towards the speaker (example 7) highlighted his role in the process, whereas the hearer orientation (example 8) emphasised the importance of the hearer in the scenario.

Speaking of the orientation of requests, choices the speakers make in this regard become of great significance. Blum Kulka states that it "is one of the ways in which the native speaker signals his or her estimate of the degree of coerciveness required situationally" (Blum Kulka, 1991: 266). In light of this, it could be said that orientation towards the speaker would be preferable. Namely, the utterance expressed in the following form:

9) Can l ask you to leave this building?

would mirror a slighter amount of threat for the face of the hearer that the utterance in the form of:

10) Can you leave this building?

Furthermore, communicators might also opt for the joint (pluralized) perspective, with the aim of illustrating the nature of unity (Blum Kulka \& Levenston, 1987), e.g.:

11) Why don't we go out tonight and have some fun?

Finally, the speaker can also opt for the orientation towards the event itself (Narrog, 2012), i.e. the negotiated issue. Thus, in the example: 
12) What is the weather like in London?

the speaker indicates that the issue he or she is asking about is the focus of his/her attention.

Starting from the theoretical notions presented above, this study aims to provide answers to the following research questions:

- Which type of speech act perspective/orientation do the students use in their email requests when the addressees are their seniors?

- What kinds of addressing formulae do the students apply in their email requests and to what extent are the applied formulae unified?

- Is there a recognisable and consistent email etiquette in the Serbian language and - if not - is there a need for one?

- Is there a need for educators to take a more active role in guiding their students through the process of appropriate electronic communication?

\section{Method}

\section{Data and Subjects}

The analysed language corpus consists of 100 emails sent to a faculty member over a period of several semesters. The electronic messages were written by university students (native speakers of Serbian, students of a faculty of philology - Serbian NSs) in Serbian. For the purposes of coding and illustrating the data in English, the examples from the corpus have been translated into English by the authors, with their best efforts to provide as close to absolute equivalent translations as possible.

Both male and female students, in the 19-45 age range (the majority of them were 19-25 years old) participated in this study. The participants were duly informed about the nature of this study and willing to provide their emails for analysis.

Also, it is worth noting that all of the speakers know the addressed faculty member in person; moreover, they were enrolled in some of the faculty member's courses, and thus it could be said that their relationship represents a prototype of the studentprofessor relationship. Nonetheless, in order to make students feel comfortable and thus achieve better results, the addressee applies a communicative-humanistic teaching style which could be characterised as a student-friendly one, but still quite formal.

\section{Procedure}

In the analysis process, each request kernel/head act, within the body of the text in the received electronic message, was firstly identified. Regarding the notion of kernel, we would like to emphasise the fact that we are not using this term to refer to what Chomsky terms kernel sentences (according to: Lyons, 1994). Following the primary meaning of the noun kernel, we simply want to illustrate the position and importance of the head act.

Afterwards, requests were analysed at two levels - in terms of the kernels' orientation, as well as in terms of the formulae of address used as salutations and complimentary 
closings. Given the nature of the study and having in mind the posed research questions, both qualitative and quantitative methods have been employed. However, it is worth noting that the illustrations of the observed phenomena via qualitative means are presented only with the aim of offering a broad/-er picture of the topic and are not discussed in detail for the purposes of this paper; in this regard, it is the further implementation of qualitative discussion which is of major importance concerning a deep insight into the research phenomena.

\section{Results, Discussion \& Pedagogical Implications}

\section{Head Act Orientation}

Head act orientation is a transparent phenomenon which requires neither specific linguistic analysis nor demanding cognitive operations in order for it to be noticeable. The criterion of speech act orientation becomes especially prominent in communicative contexts with hierarchically unequal participants. In the context which forms the background of this study, there are, a priori, two dimensions which lead to the potential gap between the communicators; first, requests bear inequality sui generis; second, a teacher-professor relationship per se includes hierarchical asymmetry.

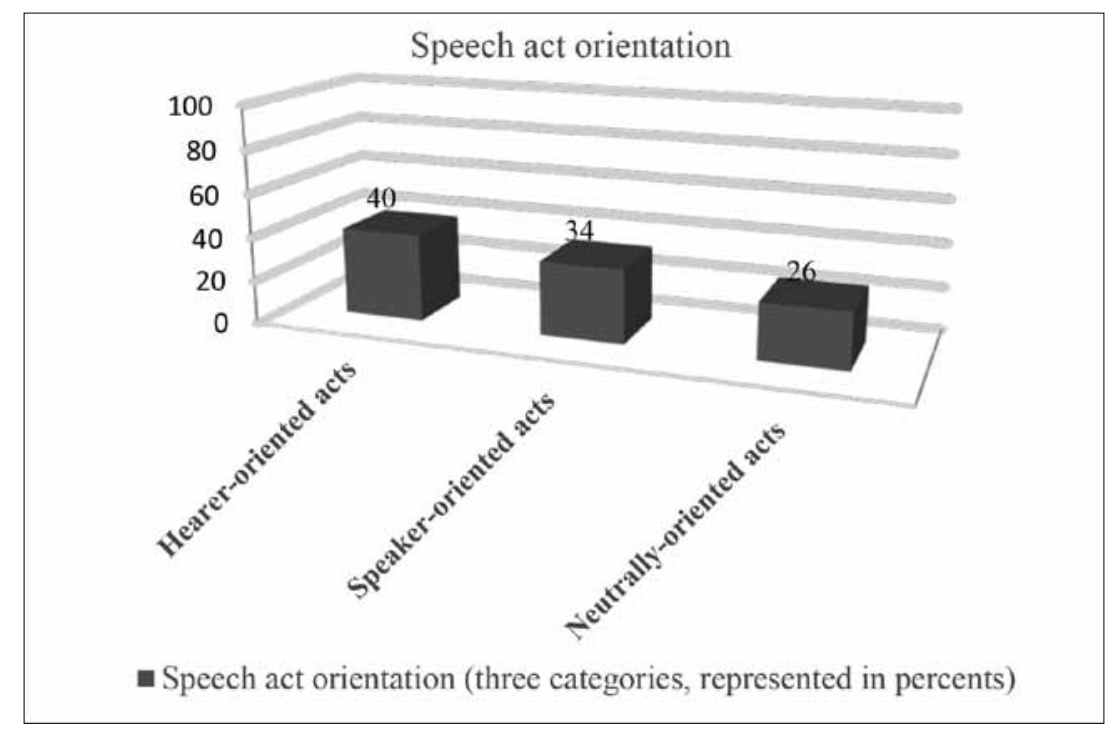

Figure 1. Speech act orientation

Despite the fact that the participants of the study were included in a communicative scenario mirroring a prototypical speaker-hearer inequality, we can see that Serbian NSs employed hearer orientation (40\%) more than speaker orientation (34\%) or neutral orientation (26\%) (Figure 1), e.g.: 
1) ... (I am very sorry to bother you) [...] Have you corrected our tests?!...;

2) ... Can you send me an example of an inner monologue...;

3) ... Can you send me the list of the topics for written assignment (If you have a softcopy in your computer)...;

4) ... Can you just send me the materials for the exam [...] and do you know the date and time of the exam?...;

5) ... (I have heard that I need some more materials apart from the Hotel and Catering part) [...] Do you maybe have them?...;

6) ... If you could briefly explain some notions concerning our presentations (so that I can be sure about what I should do)?...

Applying hearer orientation, the speaker, undoubtedly, imposes on the hearer. Anyhow, some of the examined examples (such as: e.g.16, 17, 18) do show the speaker's awareness of the imposition and his willingness to minimise its possible effects on the hearer. Namely, the speaker has decided to use some lexical means, within the utterance where there is the speech act of requesting, which mirrors the mentioned willingness, so there are words like: just (example 16), maybe (example 17) and briefly (example 18), using which the speaker tried to distance himself from the centre of the proposition to a certain degree. Even though the modification of a speech act with the usage of lexical (or syntactic) means does not represent one of the core interests of this paper, we wanted to highlight the fact that there existed the need for illocutionary force softening on the part of the speaker, even though these requests were oriented towards the hearer. Apart from lexical means, the participants of the study also occasionally used syntactic means to soften the illocutionary force of their speech acts; the usage of the modal verb could (example 18), which per se includes a level of tentativeness, reflects more formality and politeness on the part of the speakers.

Hearer orientation of the speech act was followed by speaker orientation, and in this way the speakers showed their readiness to have all the illocutionary force posed before their faces rather than the face of their addressee, e.g.

7) ... I want to inform you that I am not satisfied with the results I have obtained and that I would like to take the test again...;

8) ... I am kindly asking for the information about the exam...;

9) ... _ am writing to you about the instructions for the test correction...;

10) .... just wanted to ask you about the Applied Linguistics' materials...;

11) ... I am interested in whether I should apply for the exam again?....

As can been seen from the above examples, the requests characterised by speaker orientation, mostly mirror the so-called want or need statements (Blum Kulka, 1987), and were performed in the form of affirmative sentences, rather than questions, which put the hearer in the position to recognise and interpret them as requests. Even though a prototype of a request is the one with the usage of a performative verb (Marmaridou, 2000), a common request is performed in the form of a question (mostly with the usage of a modal verb). Apart from the linguistic means of a head act orientation, we can also notice that the students use both some lexical means, such as the words kindly (example 20) and just (example 22) and syntactic means, like the usage of a past tense form (example 22), which also serves for the purpose of distancing from the propositional content. 
Neutral orientation indicates that the matter in question is in the focus of the speakers' attention. In this way, the speakers neither threaten the hearer's nor their face/-s, e.g.

12) ... Is there a possibility for taking the test on Friday?...

13) ... Is it necessary to find and read some sources before the beginning of the term?...

14) ... Will there be chances for the correction of the test?...

15) ... Should the essay be written in English?...

16) ... Will there be an exercise on conditional sentences included in the test?...

The students' choice of the orientation towards the questioned notion also illustrates the speakers' need to show the extent to which they find the issue significant, and for that very reason these requests are performed in medias res.

\section{Address Form - Salutations}

Addressing terms, realised via salutations and complimentary closings, applied in different epistolary forms, do not only have the potential to mirror the relationship between the interlocutors, but they can also have a rather strong effect on the outcome of the communicative process. As a result, the choices concerning addressing forms become an issue of importance for communicators (Figure 2).

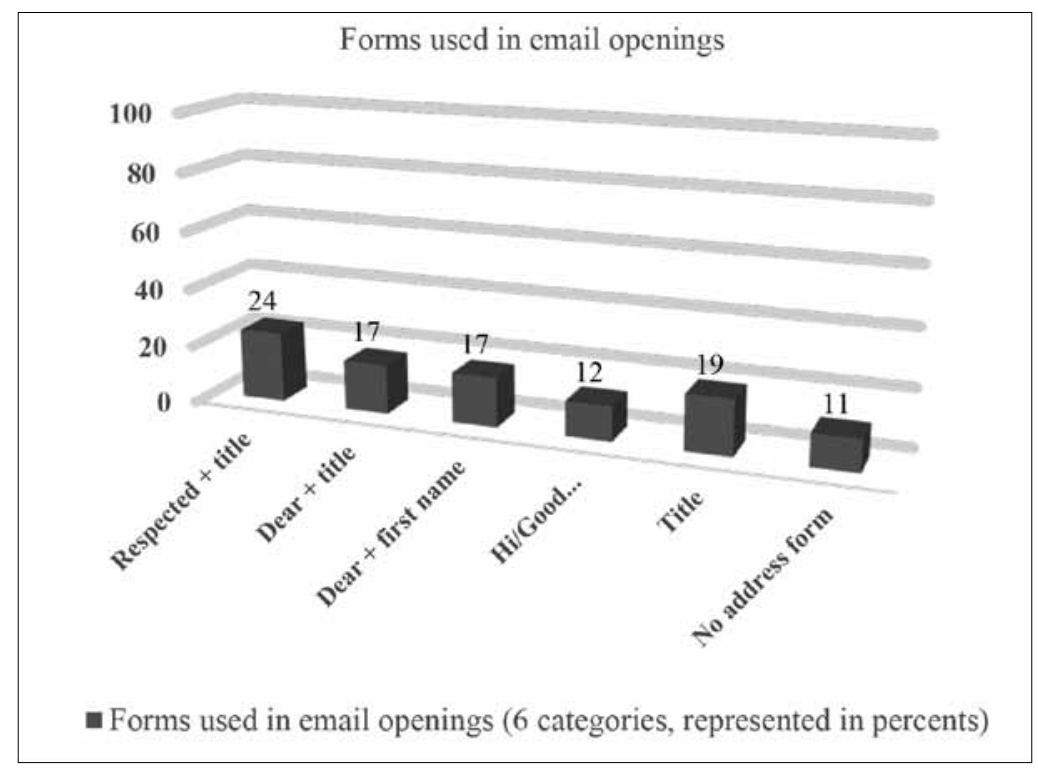

Figure 2. Forms used in email openings

The analysis of the gathered data has shown that the Serbian NSs largely opted for the opening formula of: Respected + title (24\%), e.g.

1) Respected professor, I want to ask you whether you can bring a book for me...

By using this formula, the speakers did express a quite significant level of pragmatic competence. However, it is worth mentioning that the usage of the mentioned adjective 
might appear somewhat strange in present-day English (speaking world), as constructions with this adjective used as the (pre-) modifier to a noun are not common in English anymore; they would not imply a higher level of politeness but seem not natural enough. On the other hand, in the contemporary Serbian language, which (unlike English) recognises the $T / V$ (Brown \& Gilman, 1960) forms of address, the patterns with the adjective "respected" are still used in epistolary forms.

Two language formulae were used on an equal number of occasions and these are the formulae of Dear + title (17\%) and Dear + first name (17\%), e.g.

2) Dear professor I would like to ask you to send me the source again...

3) Dear Marijana, I need a piece of advice...

The usage of the patterns including the adjective "dear" could be interpreted in two ways. First, this language formula, belonging to the English language, has become widely applied in other languages, as English is the language in which a significant amount of computer-mediated messages has been exchanged. Second, opting for the adjective "dear" instead of "respected" (especially in the cases in which the name was used after the adjective) could mirror the students' wish to minimise the neutral gap in the studentprofessor relationship.

A number of emails were opened with the language formula of Title (19\%), e.g.

4) Professor I would like you to send me the material needed...

The usage of the title of the addressee does show formality and indirectness; however, opting solely for the title, without the first or family name, can also have a few possible interpretations - the students could have been unsure about the name/surname of the addressee; they may have not have been sure about the adequate language pattern with which to begin the email or they may have simply wanted to map the addressing principle they use in everyday, face-to-face interaction when communicating with the addressed person.

A similar number of email requests was received, on one hand, with no opening at all $(11 \%)$ and, on the other hand, starting with some formulaic daily greetings expression (12\%) such as: good morning, good afternoon, hi, etc. Even though these two categories could even be perceived as a single one, as the greetings could hardly be considered addressing forms, we wanted to make a distinction between them in the analysis process, since the former, e.g.

5) If you can forward the PPT presentation to me...

illustrates a mere need on the part of the student to present the request as an imperative and crucial issue and to get a prompt answer, whereas the latter, e.g.

6) Good evening. I wanted to ask you, if that is not a problem, to send me the email of $x x .$. does show a tendency on the part of the speaker to start the communication with a kind of an opener.

Even though the above examples do not, in our view, represent par excellence models to be followed in email etiquette, we find their tendency to equate emails to text messages a phenomenon that is likely to spread in the future. 


\section{Address Form - Complimentary Closings}

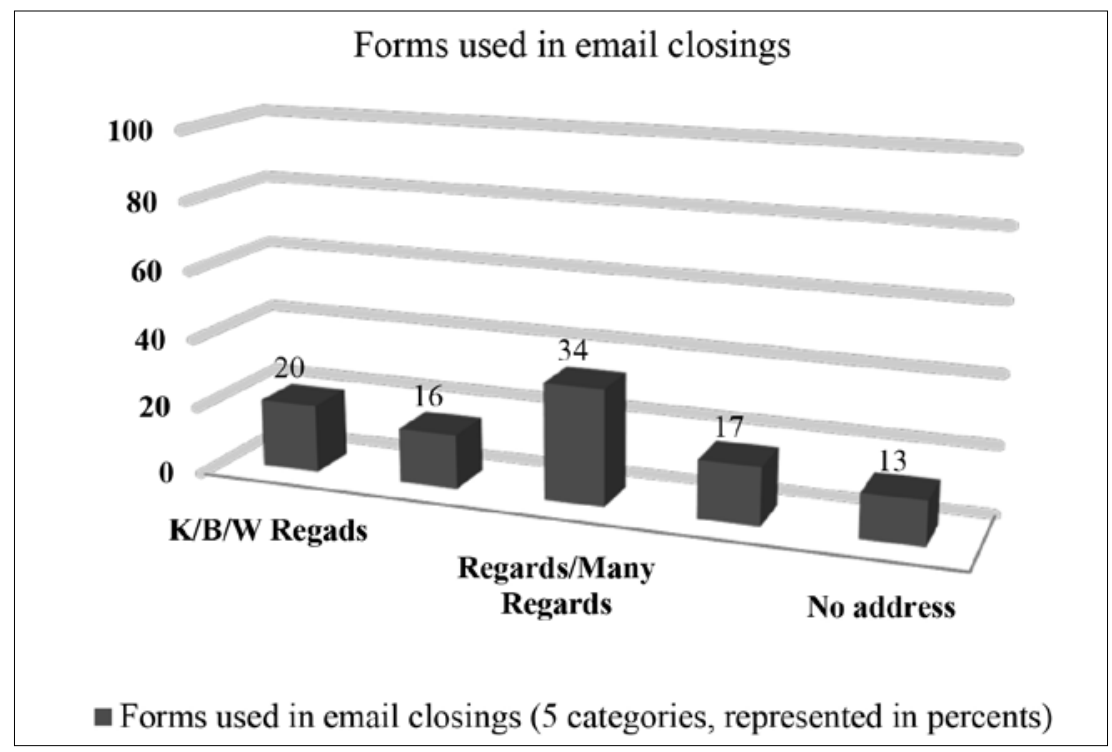

Figure 3. Forms used in email closings

Five different language formulae were found in closing to the Serbian NSs' emails (Figure 3). First, there was the formula of Regards/Many Regards (34\%). Since this formula is felt to be a semi-formal end in a communicative scenario, we tend to believe that the speakers wanted to express their relaxed tone via this formula. Next, there is the similar ending expression of Kind/Best/Warm regards (20\%), which, given the employed (pre-) modification to the noun regards, does denote a more polite and formal way of complimentary closing than the abovementioned one of Regards/Many regards.

Second, the Respectfully (16\%) expression, a highly formal formula of a complimentary closing, appeared on various occasions; then again, it is worth mentioning that this pattern was used both in combination with very formal (Respected+title) and less formal openings to emails (Dear+first name). Speaking of inconsistencies with regard to the appropriate combinations of opening and closing formulae, we would also like to mention the fact that the closings in the form of Kind/Best/Warm regards were employed both in the cases when emails were opened with the Dear + title formula and on the occasions when the formula Dear + first name was used.

Furthermore, some of the examined emails included no closing formulae at all (13\%), and, observing the emails as a whole, we noted that only those emails received with no opening had no closing - namely, they consisted of the email body solely. As we have already noted before, we find this situation a par excellence indicator of the speakers' need to present the required matter as urgent.

Finally, a number of emails were closed with an expression of thanks, i.e. in the form of Thank you (17\%), which does not represent an adequate addressing means for closing an email, but does imply the wish of the author of the message to show his respect for the addressee. 
The examined behaviour of Serbian NSs in the processes of computer-mediated communication could not be described as a mere pragmatic failure. The above presented results could be pedagogically interpreted in several directions, each of them having a certain form of pedagogical intervention in its very foundation. First, the inconsistency regarding the appropriate email patterns could represent a need for a suggestion regarding adequate standard linguistic patterns in email communication in one's native language/-s. Second, relying on the obtained results, teachers (and/or educational institutions) should bear in mind that present-day students tend to address them in many different (sometimes even unexpected) ways. Bearing that in mind, it is advisable for teachers to take on an active role in the process of making students aware of context-dependent communication in hierarchically unequal settings. Furthermore, it is worth noting that students would not only hugely benefit from explicit guidelines concerning adequate patterns, but also from some hands-on experience about the right/wrong email behaviour in different settings (i.e. via insight into good and bad samples). Finally, since cultural influence/transfer has also been noticed within the examined language corpus, special attention on the part of the teachers should be paid to cultural differences and models.

\section{Conclusions, Limitations of Research and Implications for Future Research}

Analysis of the data suggests that the findings of the study illustrate some components of the nature of Serbian in the process of computer-mediated communication. In order to examine the notion of pragmatic awareness in contemporary epistolary forms, a hierarchically unequal scenario was created. Namely, not only were the communicators of unequal hierarchical power, one of them being dominant and the other recessive, but they were also supposed to exchange the speech act of requesting, the nature of which is unequal per se.

Within the set communicative scenario, Serbian NSs proved to be only partly pragmatically aware, as they failed to employ context-appropriate and consistent language patterns. First, the results concerning speech act orientation showed that this linguistic strategy did not reflect pragmatic awareness - namely, despite the fact that in the role of the addressee there was a hierarchically dominant person, the predominant hearer orientation of the posed requests seemed to threaten his/her integrity. In any case, the noted, though not very frequent, tendency of Serbian NSs to employ other linguistic modifying strategies did mirror their awareness of the communicative scenario they were part of.

Second, it has been concluded that the language matrix of Serbian NSs does possess diverse linguistic formulae which can be used for opening and closing email messages, but these formulae were rarely properly combined. Since the language with the widest usage within the global scope of CMD is English, it is not surprising that Serbian implements some calques from English. Furthermore, the observed tendency of Serbian NSs to mix semi-formal with very formal address forms, leads us to believe that the students did not intend to be impolite but aimed to narrow the wide gap within the student-professor relationship. As it has been noted before, educators should bear the above-stated in mind 
- which could both inform them about what can be expected in communicative scenarios of a similar type and highlight the role they could play with the aim of achieving proper electronic and hierarchically-unequal communication.

In conclusion, it could be said that the conducted study has provided some information regarding the patterns in communication between hierarchically unequal communicators. With regard to this, it is worth noting that the illustrated data represent natural, real communication that has occurred in an academic setting. Given the fact that the subjects were unguided in the process of composing emails, all the examined data represent a valuable, spontaneous language set. Consequently, the results of the study could serve as a reliable guide to teachers who work either in similar or different settings.

Finally, in order to obtain a more vivid and broader picture of the topic, a larger data sample could be used (including both more students and teachers). Also, we do believe that the implementation of more categories for examination (one of them being teachers' attitude towards the emails they receive from their students) would yield more important information, lead to additional conclusions and thus provide some new pieces of advice on how to address this issue. Lastly, similar-type research can be conducted using a different data collection instrument, e.g. a discourse completion test (DCT); given the fact that DCTs represent elicitation instruments, a comparison between naturally composed and elicited emails could be provided.

\section{References}

Austin, J.L. (1962). How to Do Things with Words. Cambridge: Harvard University Press.

Bauer, L. (2004). Morphological Productivity. Cambridge: Cambridge University Press.

Blum Kulka, S. \& Levenston, E.A. (1987). Lexical-grammatical Pragmatic Indicators. Studies in Second Language Acquisition, Vol. 9, No. 2, 155-170.

Blum Kulka, S. (1987). Indirectness and Politeness in Requests: Same or Different. Journal of Pragmatics, Vol. 11, No. 2, 131-146.

Blum Kulka, S. (1991). Interlanguage Pragmatics: The Case of Requests. In R. Phillipson, E. Kellerman, L. Selinker, M. Sharwood Smich \& M. Swan (Eds.), Foreign/Second Language Pedagogy (pp. 255-272). Clevedon: Multilingua Matters.

Brown R. \& Gilman A. (1960). The Pronouns of Power and Solidarity. In T. A. Sebeok (Ed.), Style in Language (pp. 103-127). Cambridge: MIT Press.

Ceruzzi, P.E. (2003). A History of Modern Computing. Cambridge: MIT Press.

Chomsky, N. (2006). Language and Mind. Cambridge: Cambridge University Press.

Crystal, D. (2003). English as a Global Language. Cambridge: Cambridge University Press.

Crystal, D. (2006). Language and the Internet. Cambridge: Cambridge University Press.

Durham, M. (2007). Language Choice on a Swiss Mailing List. In B. Danet \& S.C. Herring (Eds.) The Multilingual Internet: Language, Culture, and Communication Online (pp. 319-339). Oxford: Oxford University Press.

Dürscheid C. \& Frehner C. (2013). Email Communication. In S.C. Herring, S. Dieter \& T. Virtanen, (Eds.). Pragmatics of Computer-Mediated Communication (pp. 35-54). Berlin: Mouton de Gruyter. 
Filipović, R. (1996). English as a Word Donor to Other Languages of Europe. In R.R.K. Hartmann (Ed.). (1996). The English Language in Europe (pp. 37-46). Exeter: Intellect.

Filipović, R. (1986). Teorija jezika u kontaktu. Zagreb: JAZU.

Fraser, B. (2010). Pragmatic Competence: The Case of Hedging. In G. Kaltenböck, M. Mihatsch \& S. Schneider (Eds.). New Approaches to Hedging (pp. 15-34.). Bingley: Emerald Group Publishing.

Grundy, P. (2008). Doing Pragmatics. London: Routledge.

Hafner, K. \& Lyon, M. (1996). Where Wizards Stay up Late: the Origins of the Internet. New York: Touchstone.

Herring, S.C. (Ed.). (1996). Computer-Mediated Communication: Linguistic, Social and Cross-Cultural Perspectives. Amsterdam: John Benjamins.

Herring, S. (2003). Computer-mediated Discourse. In D. Schiffrin, D. Tannen \& H.E. Hamilton (Eds.). The Handbook of Discourse Analysis (pp. 612-634). Oxford: Blackwell Publishing.

Howe, N. \& Strauss, W. (2009). Millennials Rising: The Next Great Generation. New York. Knopf Doubleday Publishing Group.

Internet Users in the World (2016). Retrieved June 28, 2016 from the World Wide Web http://www.internetlivestats.com/internet-users/

Kecskes, I. (2014). Intercultural Pragmatics. Oxford: Oxford University Press.

Labov, W. \& Fanshel, D. (1977). Therapeutic Discourse: Psychotherapy as Conversation. New York: Academic Press.

Leech, G.N. (1983). The Principles of Pragmatics. London: Longman.

Lyons, J. (1994). Semantics 2. Cambridge: Cambridge University Press.

Marmaridou, S.S.A. (2000). Pragmatic Meaning and Cognition. Amsterdam - Philadelphia: John Benjamins.

Messner, M. \& Garrison, B. (2009). Internet Communication. In D.W. Stacks \& M.B. Salwen (Eds.). (2009). An Integrated Approach to Communication Theory and Research (pp. 389-405). New York: Routledge.

Modiano, M. (2009). EIL, Native-speakerism and the Failure of European ELT. In F. Sharifian (Ed.), English as an International Language. Perspectives and Pedagogical Issues (pp. 58-77). Bristol: Multilingual Matters.

Narrog, H. (2012). Modality, Subjectivity, and Semantic Change: A Cross-Linguistic Perspective. Cambridge: Cambridge University Press.

Petrazzini, B. \& Kibati, M. (1999). The Internet Infrastructure in Developing Countries. Communications of $A C M$, Vol. 42, No. 6, 31-36.

Pritchard, A. (2007). Effective Teaching with Internet Technologies. Pedagogy and Practice. London: Paul Chapman Publishing.

Raymond, E.S. (1993). The New Hacker's Dictionary. Cambridge: MIT Press.

Searle, J.R. (1969). Speech Acts: An Essay in the Philosophy of Language. Cambridge: Cambridge University Press.

Simkins, S. \& Maier, M. (Eds.) (2010). Just-in-time Teaching. Across the Disciplines. Across the Academy. Sterling, Virginia: Stylus. 


\title{
DA LI SU SAVREMENOJ EPISTOLARNOJ KOMUNIKACIJ POTREBNE PEDAGOŠKE INTERVENCIJE: SLUČAJ KOMUNIKACIJE IZMEĐU STUDENATA I PROFESORA
}

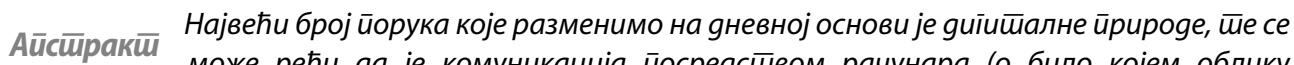
може рећи gа је комуникација йосреgсшивом рачунара (о било којем облику рачунара gа се раgи) зайраво йосӣала уобичајена у свим сферама љуgскої gеловања. И йореg неgвосмислене йрисуйносии ової облика комуникације, нереш̄ко су језички обрасии које ћемо

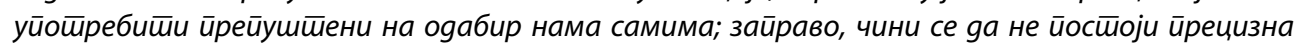

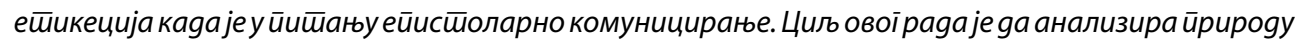

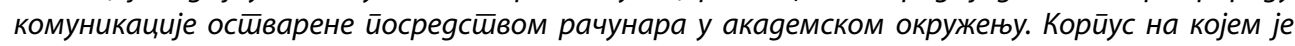

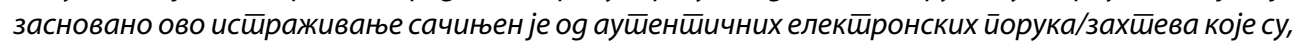

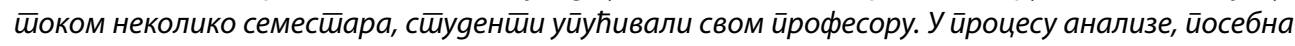
йажња је йосвећена језичким формулама којима су зайочейе, йј. завршене gобијене ӣоруке, као

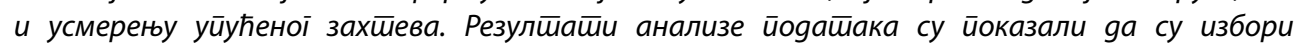

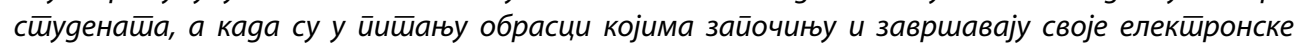

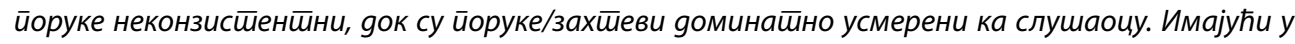

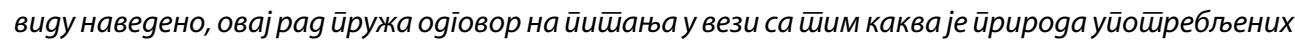
језицких образаца и, у исйо време, освейљава улоїу ӣрофесора/йреgаваца и/или образовних

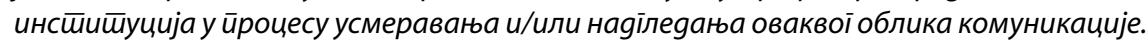

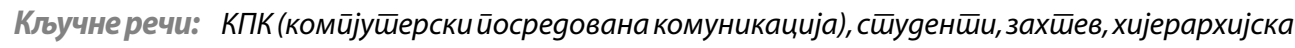

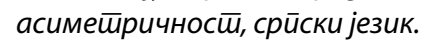

\section{НУЖНЫ ЛИ СОВРЕМЕННОЙ ЭПИСТОЛЯРНОЙ КОММУНИКАЦИИ ПЕДАГОГИЧЕСКИЕ ВМЕШАТЕЛЬСТВА: ПРИМЕР КОММУНИКАЦИИ МЕЖДУ СТУДЕНТАМИ И ПРОФЕССОРАМИ}

\begin{abstract}
Резюме Самое большое количество сообщений, которыми ежедневно обмениваемся несет (любой вид компюютера) фактически стала обычным явлением во всех сферах человеческой деятельности. Несмотря на существование данной формы коммуникации, языковые средства, которые при этом используются, часто выбираются свободно и, в самом деле, кажется, что нет точного этикета, когда дело доходит до эпистолярного общения. Цель данной работы заключается в анализе характера коммуникачии с помощью компьютера в академической среде. Корпус данного исследования состоит из подлинной электронной переписки - сообщения и запросы, с которыми в течение нескольких семестров, студенты обращались к своему профессору. В прочессе анализа особое внимание уделялось лингвистическим формулам, $c$ которым начинались / заканчивались полученные сообщения, а также направлению запроса. Результаты анализа показали, что выборы студентов, когда речь идет о языковой модели, с которой начинаются изаканчиваются ихэлектронные письма непоследовательны, в то время как сообщения / запросы в основном направлены на слушателя. С учетом вышеизложенного, данная работа дает ответ на вопросы относительно природы используемых языковых средств и, в то же время, освещает роль профессоров / преподавателей и / или учебных заведений в прочессе направления и / или контроля этой формы коммуникации.
\end{abstract}

Ключевыеслова: КОК (компьютерно-опосредованная коммуникачия), студенты, требование, иерархическая асимметрия, сербский язык. 